\title{
KEMANTAPAN AGREGAT TANAH PADA LAHAN PRODUKSI RENDAH DAN TINGGI DI PT GREAT GIANT PINEAPPLE
}

\author{
Made Pujawan, Afandi, Hery Novpriansyah \& Karden E.S. Manik \\ Jurusan Agroteknologi, Fakultas Pertanian Universitas Lampung \\ Jl. Prof. Dr. Soemantri Brodjonegoro, No.1 Bandar Lampung 35145 \\ E-mail: madepujawan3003@gmail.com
}

\begin{abstract}
ABSTRAK
Penelitian ini bertujuan untuk mengetahui pengaruh kemantapan agregat tanah terhadap hasil produksi. Penelitian ini dilaksanakan dari bulan september sampai pada bulan Juli 2015 di PT Great Giant Pineapple (PT. GGP). Lampung Tengah. Penelitian ini mengunakan metode survei. Untuk pengambilan sampel dilakukan secara langsung di PT. GGP pada lokasi lahan 26B produksi rendah dan produksi tinggi. Lokasi 26B mempunyai luas lahan kurang lebih 8,30 ha dan terbagi menjadi 2 petak yang dipisahkan oleh jalan. Penentuan titik sampel secara diagonal,masing-masing di ambil 3 titik di lahan produksi rendah dan produksi tinggi. Pembuatan minipit dibuat untuk menentukan warna tanah dan pengambilan sampel tanah diseetiap titik, pengambilan contoh tanah diambil disetiap kedalaman dari 0-20, 20-40, 40-60. analisis contoh tanah dilakukan di Laboratorium Ilmu Tanah, Jurusan Agroteknologi, Fakultas Pertanian, Universitas Lampung untuk mengetahui sifat fisik tanah. Untuk perlakuan analisis sampel tanah dipisahkan disetiap kedalaman, sehingga diperoleh 1 titik ada 3 sampel tanah pada kedalaman 0-20, 20-40, 40-60 dan pengambilan sampel tanah ada sebanyak 6 titik, 3 titik produksi rendah dan 3 titik di produksi tinggi sehingga jumlah sampel keseluruhan ada 18 sampel tanah. Tanah sebelum dianalisis dilakukan pengeringan udara sela 1-2 hari, hal ini dilakukan untuk mendapatkan kapasitas lapang. Untuk menentukan kelas kemantapan agregat perlu dilakukan analisis dengan menggunakan metode ayakan kering dan basah, dan didapatkan nilai RBD pengayakan kering dan RBD pengayakan basah. Kemudian dilakukan perhitungan indeks kemantapan agregat dan hasil nilai dari indeks kemantapan agergat dimasukan kedalam klasifikasi kemantapan agregat untuk mengetahui hasil sampel tanah masuk dalam kelas kemantapan mantap atau tidak mantap. Hasil penelitian menunjukkan bahwa pada lokasi lahan 26B baik yang produksi rendah maupun produksi tinggi sama-sama mempunyai kemantapan agregat sangat mantap.
\end{abstract}

Kata kunci: kemantapan agregat, sifat fisik tanah.

\section{PENDAHULUAN}

Nanas merupakan salah satu tanaman hortikultura, yang sangat cocok dibudidayakan didaerah tropis. Tanaman ini berasal dari amerika selatan (Brazilia). Tanaman nanas dibawa masuk ke Indonesia oleh para pelaut Spanyol dan Portugis pada tahun 1599. Tanaman ini akan tumbuh baik dengan curah hujan yang cukup, di Indonesia hampir semua daerah dapat dibudidayakan tanaman nanas. Tanaman nanas merupakan tanaman yang memiliki nilai ekonomi yang cukup tinggi, sehingga dapat dikembangkan menjadi sebuah usaha, karena buah nanas mempunyai rasa yang manis, aroma yang khas dan bentuk yang menarik, selain itu tanaman nanas memiliki kandungan vitamin A, B1, B2, C, kapur, besi, dan lain-lain (Ashari, 1995).

Tanah merupakan media tanam yang digunakan untuk budidaya tanaman nanas, selain sifat biologi dan kimia,tanah yang bagus harus memiliki sifat fisik tanah yang baik. Karena tanpa disertai sifat fisik tanah yang baik maka produksi tanaman tidak akan mencapai pertumbuhan yang optimal. Hal ini dikarenakan tidak dapatnya akar tanaman menyerap unsur-unsur hara yang ada didalam tanah secara maksimal dan secara normal. Selain itu jika sifat fisik tanah kurang baik maka perkembangan akar tanaman akan terganggu karena sulitnya akar menembus tanah, sehingga penyerapan unsur hara yang ada di dalam tanah akan terganggu. Apabila sifat-sifat tanah tersebut terpenuhi maka akan dihasilkan kondisi tanaman nanas yang sehat, subur, dan vigor (kekokohan) tanaman yang lebih baik (Haridjaja, 1996).

PT. GGP merupakan salah satu perusahan terbesar di Indonesia yang membudidayakan tanaman nanas, hampir sebagian besar jenis tanah di PT. GGP adalah jenis tanah Ultisol. Jenistanah Ultisol ini tergolong lahan marginal yang tingkat produktivitasnya rendah. Kandungan hara pada tanah ultisol umumnya rendah karena pencucian basa berlangsung intensif, sedangkan kandungan bahan organik rendah karena proses dekomposisi berjalan cepat. Tanah Ultisol memiliki solum yang dangkal, permeabilitas yang lambat hingga sedang, 
dan kemantapan agregat lemah sehingga sebagian besar tanah ini mempunyai kapasitas memegang air yang rendah dan peka terhadap erosi. Kerentanan terhadap erosi membuat tanah akan semakin cepat berkurang kesuburannya terutama pada lapisan atas dan akan terakumulasi di bagian yang lebih rendah.

Permasalahan utama pada jenis tanah Ultisol disamping kondisi perharaannya yang tergolong miskin juga sifat fisiknya yang kurang menguntungkan.Salah satu sifat fisiknya yang menonjol yaitu tekstur tanah yang dicirikan oleh kandungan liat yang tinggi dan debu rendah. Kondisi tekstur ini mendasari banyaknya masalah lain pada Ultisol, diantaranya masalah retensi dan transmisi air, pemadatan tanah, dan penetrasi akar. Distribusi pori yang kurang seimbang, karena didominasi oleh pori mikro, menyebabkan aerasi kurang baik, laju infiltrasi rendah, dan peka erosi.

Tanah jenis Ultisol umumnya bertekstur lempung dan didominasi oleh mineral kaolinit yang tidak banyak memberikan kontribusi pada kapasitas tukar kation tanah. Kapasitas tukar kation hanya bergantung pada kandungan bahan organic dan fraksi liat. Penanaman secara terus menerus tanpa tindakan konservasi tanah dan air, pengelolaan bahan organik, dan pemupukan berimbang dapat merusak tanah. Kerusakan tanah dipercepat oleh penggunaan alat mesin pertanian (alsintan) yang membuat tanah menjadi padat. Untuk meningkatkan produktivitas tanah Ultisol dapat dilakukan melalui perbaikan tanah (ameliorasi), pemupukan, dan pemberian bahan organik. Bahan organik akan meningkatkan kesuburan tanah, baik secara fisik, kimia maupun dari segi biologis tanah.

Kemantapan agregat sangat penting bagi tanah pertanian dan perkebunan. Agregat yang stabil akan menciptakan kondisi yang baik bagi pertumbuhan tanaman. Agregat dapat menciptakan lingkungan fisik yang baik untuk perkembangan akar tanaman melalui pengaruhnya terhadap porositas, aerasi dan daya menahan air. Pada tanah yang agregatnya, kurang stabil bila terkena gangguan maka agregat tanah tersebut akan mudah hancur. Butir-butir halus hasil hancuran akan menghambat pori-pori tanah sehingga bobot isi tanah meningkat, aerasi buruk dan permeabilitas menjadi lambat. Kemantapan agregat juga sangat menentukan tingkat kepekaan tanah terhadap erosi. Kemampuan agregat untuk bertahan dari gaya perusak dari luar (stabilitas) dapat ditentukan secara kuantitatif melalui Aggregate Stability Index (ASI). Indeks ini merupakan penilaian secara kuantitatif terhadap kemantapan agregat. Faktor-faktor yang mempengaruhi kemantapan agregat antara lain pengolahan tanah, aktivitas mikroorganisme tanah, dan penutupan tajuk tanaman pada permukaan tanah yang dapat menghindari splash erotion akibat curah hujan tinggi. Agregat tanah terbentuk karena proses flokulasi dan fragmentasi. Flokulasi terjadi jika partikel tanah yang pada awalnya dalam keadaan terdispersi, kemudian bergabung membentuk agregat. Sedangkan fragmentasi terjadi jika tanah dalam keadaan masif, kemudian terpecah-pecah membentuk agregat yang lebih kecil (Santi et al., 2008).

\section{BAHAN DAN METODE}

Penelitian ini dilaksanakan di PT. GGP Terbanggi Besar Lampung Tengah pada bulan September sampai dengan juni 2015 pada areal pertanaman nanas (Ananas Comosus). Pengambilan sampel tanah dilakukan pada lokasi 26B, pada dasarnya lokasi 26B dibagi menjadi dua petak yang dipisahkan oleh jalan, petak sebelah kiri berproduksi tinggi dan sebelah kanan berproduksi rendah. Untuk analisis sifat fisik tanah dilakukan di Laboratorium ilmu tanah, jurusan Agroteknologi, Fakultas Pertanian, Universitas Lampung, Bandar Lampung.

Alat-alat yang dipergunakan diantaranya adalah sebagai berikut: cangkul, meteran, oven, spidol, gunting, plastik, penggaris, hydrometer, ring sampel, penumbuk dari kayu ,satu set ayakan, buret, cawan, desikator, hot plate, ember besar, timbangan listrik dan corong plastic, dan alat-alat labolatorium untuk analisis tanah. Sedangkan untuk bahan yang diperlukan adalah sampel tanah, air, dan larutan calgon.

Metode yang digunakan pada penelitian ini adalah metode survei.Pada lokasi 26 B yang disurvei dilakukan pembuatan minipit dan pengambilan sampel tanah sebanyak enam titik. Masing - masing tiga titik produksi rendah dan tiga titik produksi tinggi dengan kedalaman $0-20,20-40$ dan $40-60 \mathrm{~cm}$. pengambilan contoh tanah dilakukan secara diagonal. Variabel yang diamati pada penelitian ini adalah penetapan Kemantapan Agregat pada lokasi produksi tinggi dan rendah dengan menggunakan metode ayakan kering dan basah, tekstur dilakukan dengan metode hidrometer, Analisis kerapatan isi dilakukan dengan metode clod. Analisis data dilakukan dengan membandingkan data yang diperoleh pada saat penelitian dibandingkan dengan kriteria sifat fisik tanah yang telah baku.

\section{HASIL DAN PEMBAHASAN}

Penentuan kemantapan Agregat tanah pada lokasi lahan 26B produksi rendah dan produksi tinggi dapat dilihat pada Gambar 1. Dari kedua hasil data tersebut dapat diketahui pada lokasi lahan 26B yang produksi rendah maupun produksi tinggi kelas agregatnya 
tergolong dalam kelas sangat mantap. Hal ini dikarenakan di PT. GGP melakukan penambahan bahan organik yang cukup, selain itu sistem pengolahan tanah yang dilakukan PT. GGP yaitu dengan cara membalikkan tanah lapisan atas ke lapisan bagian bawah (20-40). Setelah pengolahan tanah bahan organik yang terdapat di bagian atas akan berpindah ke lapisan bagian tengah. Tanah yang banyak yang mengandung bahan organik akan memiliki sifat tanah yang baik, seperti Agregat tanah yang mantap, karena bahan organik dapat memperbaiki sifat fisik tanah, bahan organik mampu berperan sebagai bahan perekat yang akan terbentuknya agregat tanah dan yang memantapkan Agegat tanah. Bahan organik tanah adalah sebagai pengikat bahan semen yang akan memantapkan Agregat tanah menjadi lebih stabil.

Hasil variabel kerapatan isi lokasi 26B produksi rendah dapat dilihat pada Tabel 1. Dari Tabel 1 dapat diketahui bahwa pada kedalaman $40-60 \mathrm{~cm}$ yang

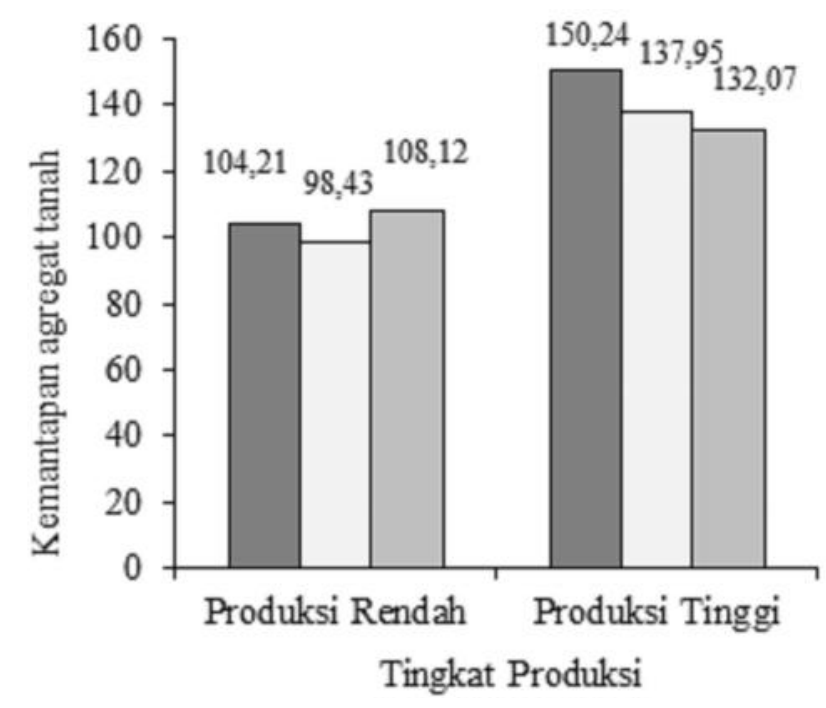

Gambar 1. Kemantapan Agregat Tanah Pada Lahan Produksi Rendah dan Produksi Tinggi. $\square=$ kedalaman tanah 0-20 cm, $\square=$ kedalaman tanah 20-40 cm, $\square=$ kedalaman tanah 40$60 \mathrm{~cm}$ bernilai $1,54 \mathrm{~g} \mathrm{~cm}^{-3}$ memiliki kerapatan isi yang tertinggi dibandingkan dengan kedalaman $0-20 \mathrm{~cm}$ dan $20-40$ $\mathrm{cm}$ yang berturut - turut memiliki nilai kerapatan isi sebesar $1,36 \mathrm{~g} \mathrm{~cm}^{-3}$ dan $1,41 \mathrm{~g} \mathrm{~cm}^{-3}$. Tabel 1 juga menunjukkan hasil variabel kerapatan isi produksi tinggi. Dapat diketahui bahwa pada kedalaman $40-60 \mathrm{~cm}$ yang bernilai $1,45 \mathrm{~g} \mathrm{~cm}^{-3}$ memiliki kerapatan isi yang tertinggi dibandingkan dengan kedalaman $0-20 \mathrm{~cm}$ dan $20-40 \mathrm{~cm}$ yang berturut - turut memiliki nilai kerapatan isi sebesar $1,29 \mathrm{~g} \mathrm{~cm}^{-3}$ dan $1,38 \mathrm{~g} \mathrm{~cm}^{-3}$. Hal ini dikarenakan pada kedalaman $40-60 \mathrm{~cm}$ memiliki kandungan bahan organik yang lebih rendah dibandingkan kedalaman $0-20 \mathrm{~cm}$ dan $20-40 \mathrm{~cm}$, sehingga mempengaruhi besarnya ruang pori tanah. Apabila ruang pori yang terdapat pada tanah semakin besar maka kerapatan isi akan semakin kecil. Kerapatan isi merupakan salah satu sifat fisik yang mengindikasikan kemampuan akar tanaman dapat menembus tanah.

Hasil analisis tekstur pada lokasi 26B produksi rendah dapat dilihat pada Tabel 2. Dari Tabel 2 dapat diketahui bahwa pada lahan produksi rendah didominasi oleh tekstur liat berpasir. Tabel 2 juga menunjukkan hasil analisis tekstur pada lahan produksi tinggi dapat diketahui bahwa pada lahan produksi tinggi didominasi oleh tekstur liat berpasir. Jika dilihat dari besarnya kandungan pasir yang terdapat pada dua lahan tersebut maka tergolong tinggi dan mengindikasikan bahwa lahan tersebut tidak terjadi genangan air pada saat hujan. Hal ini dikarenakan sifat tanah yang memiliki kandungan pasir yang tinggi memiliki sifat mudah meloloskan air sehingga aerasi baik dan dekomposisi bahan organik cepat.

Tanah dengan tekstur tanah pasir memiliki luas permukaan yang lebih kecil daripada tanah dengan tekstur liat. Dilihat dari ukuran partikelnya, partikel pasir lebih besar daripada partikel liat. Sehingga dapat disimpulkan partikel pasir lebih berat daripada partikel liat (Foth, 1978).

Kemantapan Agregat merupakan indikator yang digunakan untuk mengetahui tanah tersebut baik ataupun buruk bagi tanaman ini dikarenakan, Susunan agregat tanah atau fragmen tanah memiliki pengaruh utama

Tabel 1. Kerapatan Isi Tanah $(0-20,20-40,40-60 \mathrm{~cm})$ Pada Lahan Produksi Rendah.

\begin{tabular}{ccccccc}
\hline \multirow{2}{*}{ Lokasi } & \multicolumn{3}{c}{ Lahan Produksi Rendah } & \multicolumn{3}{c}{ Pada Lahan Produksi Tinggi } \\
\cline { 2 - 7 } & \multicolumn{3}{c}{ Kerapatan isi $\left(\mathrm{g} \mathrm{cm}^{3}\right)$} & \multicolumn{3}{c}{ Kerapatan isi $\left(\mathrm{g} \mathrm{cm}^{3}\right)$} \\
\cline { 2 - 7 } & $0-20$ & $20-40$ & $40-60$ & $0-20$ & $20-40$ & $40-60$ \\
\hline 1 & 1,40 & 1,45 & 1,60 & 1,30 & 1,43 & 1,53 \\
2 & 1,35 & 1,39 & 1,59 & 1,29 & 1,36 & 1,39 \\
3 & 1,32 & 1,39 & 1,44 & 1,29 & 1,35 & 1,43 \\
\hline Rata - rata & 1,36 & 1,41 & 1,54 & 1,29 & 1,38 & 1,45 \\
\hline
\end{tabular}


Tabel 2. Hasil analisis tekstur tanah kedalaman $(0-20,20-40,40-60 \mathrm{~cm})$ pada lahan produksi rendah dan lahan produksi tinggi.

\begin{tabular}{|c|c|c|c|c|c|c|c|c|}
\hline \multirow{3}{*}{ Lokasi } & \multicolumn{4}{|c|}{ Lahan Produksi Rendah } & \multicolumn{4}{|c|}{ Lahan Produksi Tinggi } \\
\hline & \multicolumn{3}{|c|}{ Fraksi / Partikel Tanah } & \multirow[t]{2}{*}{ Kelas Tekstur } & \multicolumn{3}{|c|}{ Fraksi / Partikel Tanah } & \multirow[t]{2}{*}{ Kelas Tekstur } \\
\hline & $\%$ Liat & $\%$ Debu & $\%$ Pasir & & $\%$ Liat & \% Debu & $\%$ Pasir & \\
\hline 1 & 45,75 & 9,70 & 44,55 & Liat Berpasir & 40,99 & 10,31 & 48,70 & Liat Berpasir \\
\hline 2 & 43,50 & 9,67 & 46,83 & Liat Berpasir & 37,13 & 10,38 & 52,49 & Liat Berpasir \\
\hline 3 & 30,79 & 10,35 & 58,86 & $\begin{array}{l}\text { Lempung Liat } \\
\text { Berpasir }\end{array}$ & 34,81 & 10,31 & 54,88 & $\begin{array}{c}\text { Lempung Liat } \\
\text { Berpasir }\end{array}$ \\
\hline
\end{tabular}

terhadap aerasi, ketersediaan air dan kekuatan tanah, sehingga berpengaruh terhadap pertumbuhan akar dan tajuk, dan mungkin pada akhirnya terhadap produksi tanaman (Dýaz-Zorita et al., 2005).

Perkembangan akar tanaman pada lokasi lahan 26B produksi rendah maupun produksi tinggi baik jika dilihat dari kelas kemantapanya yang memiliki kelas sangat mantap, tetapi jika dilihat dari nilai indexs kemantapanya produksi tinggi memiliki nilai yang lebih tinggi dibandingkan pada lokasi produksi rendah, sehingga dapat diketahui perkembangan akar tanaman pada lokasi 26B produksi rendah dari kedalaman 0-20, 20-40, berbeda dengan lokasi 26B produksi tinggi yang perkembangan akarnya bisa mencapai kedalaman 4060.

Jika hasil nilai indeks kemantapan agregat pada lokasi 26B produksi rendah dihungkan dengan nilai kerapatan isi pada Tabel 1 lokasi 26B produksi rendah dan tekstur tanah pada Tabel 3 lokasi 26B produksi rendah yang menunjukkan bahwa tekstur yang dominan pada lahan produksi rendah yaitu liat berpasir dan dibandingkan dengan nilai kerapatan isi pada tabel 1 bahwa pada kedalaman $0-20$ dan $20-40 \mathrm{~cm}$ merupakan kerapatan isi ideal untuk pertumbuhan akar tanaman nanas sedangkan pada kedalaman $40-60 \mathrm{~cm}$ merupakan kerapatan isi tidak ideal untuk pertumbuhan akar tanaman nanas sehingga akar tanaman nanas hanya dapat tembus dan tumbuh dikedalaman $0-40$ $\mathrm{cm}$. Sedangkan hasil nilai indexs kemantapan agregat pada lokasi 26B produksi tinggi dihubungkan dengan nilai hasil kerapatan isi pada Tabel 2 lokasi 26B produksi tinggi dan tekstur tanah pada Tabel 4 lokasi 26B produksi tinggi yang menunjukkan bahwa tekstur yang dominan pada lahan produksi tinggi yaitu liat berpasir dan dibandingkan dengan nilai kerapatan isi pada Tabel 1 bahwa pada kedalaman 0 - 20, 20 - 40 dan $40-60 \mathrm{~cm}$ merupakan kerapatan isi ideal untuk pertumbuhan akar tanaman nanas sehingga tanaman nanas dapat tumbuh pada kedalaman $0-60 \mathrm{~cm}$.

\section{KESIMPULAN}

Dari hasil penelitian dapat disimpulkan bahwa: Kemantapan agregat pada produksi rendah termasuk dalam sangat mantap, tekstur tanah liat berpasir, dan kerapatan isi ideal pertumbuhan akar dari kedalaman 0 - $40 \mathrm{~cm}$. Kemantapan agregat tanah pada produksi tinggi adalah sangat mantap, tekstur tanah liat berpasir, dan kerapatan isi ideal pertumbuhan akar hingga kedalaman $40-60 \mathrm{~cm}$. Pada lahan lokasi 26B pada produksi rendah dan produksi tinggi sama-sama mempunyai kelas yang sangat mantap, tetapi jika dilihat dari nilai indexs kemantapanya lokasi produksi rendah memiliki nilai lebih kecil dibandingkan dengan lokasi produksi tinggi.

\section{DAFTAR PUSTAKA}

Afandi. 2005. Penuntun Pratikum Fisika Tanah. Universitas Lampung. Bandar Lampung. $56 \mathrm{hlm}$.

Ashari, S. 1995. Hortikultura : Aspek Budidaya. UI Press. Jakarta. $485 \mathrm{hlm}$.

Balai Penelitian dan Pengembangan Pertanian. 2006. Sifat Fisik Tanah dan Metode Analisisnya. Departemen Pertanian Republik Indonesia.

Dýaaz-Zorita, M., J. H. Grove, dan E. Perfect. 2005. Soil fragment size distribution and compactive effort effects on maize root seedling elongation in moist soil. Crop Sci. 45:1417-1426 hlm.

Foth, H.D. 1994. Dasar-Dasar Ilmu Tanah. Diterjemahkan: Soenartono Adisoemarto. Erlangga. Jakarta.

Haridjaja,O., Y. Hidayat, dan S.M. Lina. 2010. Pengaruh bobot isi tanah dan perkecambahan benih kacang tanah dan kedelai. Jurnal Ilmu Pertanian Indonesia: 147-152. 
Kemper, E.W. dan R.C. Rosenau 1986. Aggregate stability and size distribution. Dalam: A. Klute (Ed.) Method of Soil Analysis. Part 1. 2nd ed. ASA. Madison. Wisconsin. 425-461 hlm.

Kurnia, U. 1996. Kajian Metode Rehabilitasi Lahan untuk Meningkatkan dan Melestarikan Produktivitas Tanah. Disertasi. Institut Pertanian Bogor. Bogor.
Martin, J.P., W.P. Martin., J.B. Page., W.A. Raney., dan J.D. De Ment. 1955. Soil Agregation. Adv. Agron. 7: 1-38.

Santi, L.P., A.I. Dariah, dan D.H. Goenadi, 2008. Peningkatan kemantapan agregat tanah mineral oleh bakteri penghasil eksopolisakarida. Jurnal Balai Penelitian Tanah. Bogor. hlm 7-8. 